MALARIA JOURNAL

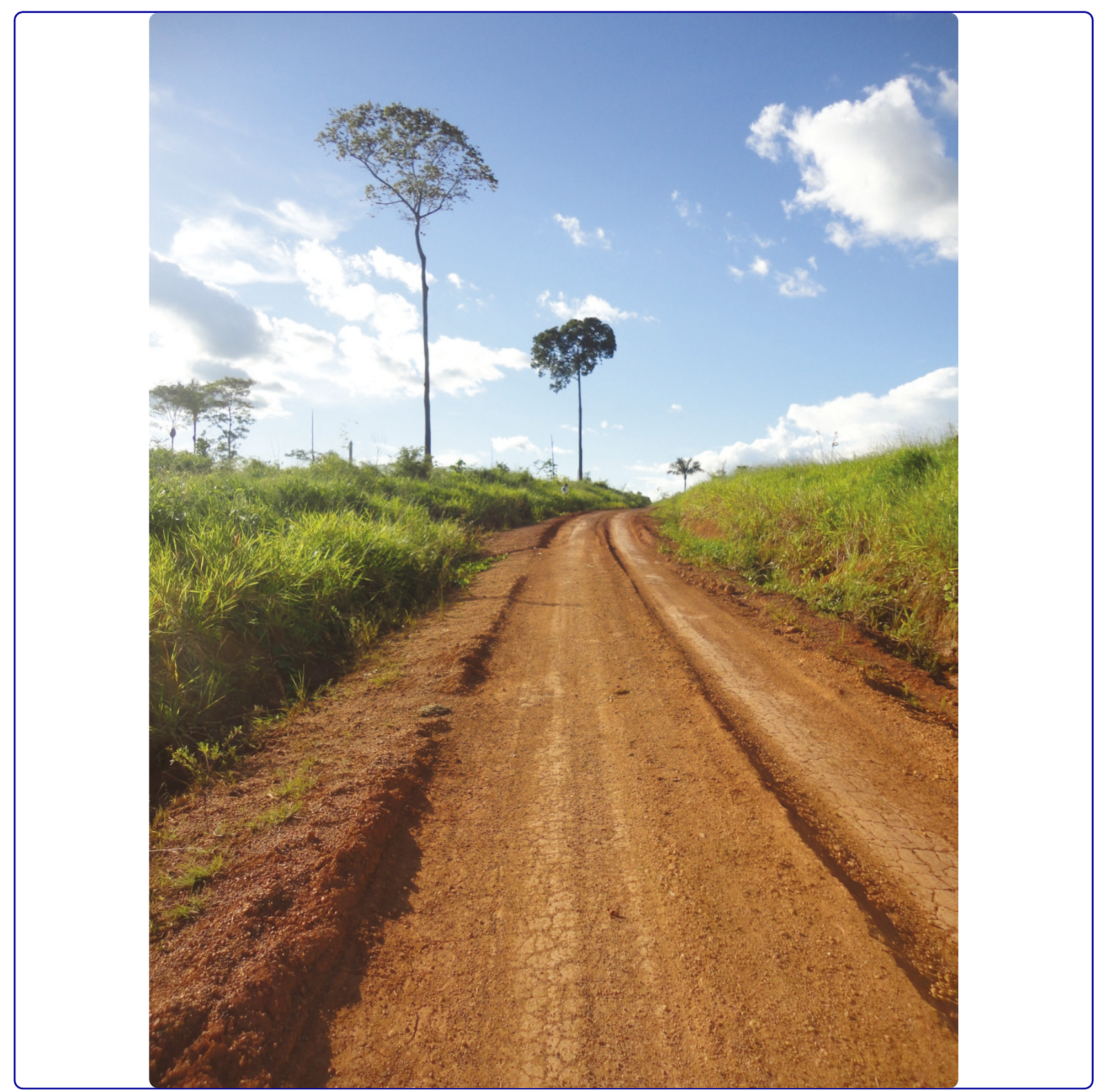

Population dynamics, structure and behavior of Anopheles darlingi in a rural settlement in the Amazon rainforest of Acre, Brazil

Moutinho et al. 


\title{
Population dynamics, structure and behavior of Anopheles darlingi in a rural settlement in the Amazon rainforest of Acre, Brazil
}

\author{
Paulo Rufalco Moutinho', Luis Herman Soares Gil', Rafael Bastos Cruz ${ }^{2}$ and Paulo Eduardo Martins Ribolla ${ }^{\text {* }}$
}

\begin{abstract}
Background: Anopheles darlingi is the major vector of malaria in South America, and its behavior and distribution has epidemiological importance to biomedical research. In Brazil, An. darlingi is found in the northern area of the Amazon basin, where $99.5 \%$ of the disease is reported.

Methods: The study area, known as Ramal do Granada, is a rural settlement inside the Amazon basin in the state of Acre. Population variations and density have been analysed by species behaviour, and molecular analysis has been measured by ND4 mitochondrial gene sequencing.

Results: The results show higher density in collections near a recent settlement, suggesting that a high level of colonization decreases the vector presence. The biting activity showed higher activity at twilight and major numbers of mosquitos in the remaining hours of the night in months of high density. From a sample of 110 individual mosquitoes, 18 different haplotypes were presented with a diversity index of 0.895 , which is higher than that found in other Anopheles studies.

Conclusions: An. darlingi depends on forested regions for their larval and adult survival. In months with higher population density, the presence of mosquitoes persisted in the second part of the night, increasing the vector capacity of the species. Despite the intra-population variation in the transition to rainy season, the seasonal distribution of haplotypes shows no change in the structure population of An. darlingi.
\end{abstract}

\section{Background}

Malaria is one of the most important tropical diseases in the world. WHO data report a total of 106 malaria-endemic countries and 151 million estimated cases in 2009 [1]. In South America, there are a high number of disease notifications in Brazil, Colombia, Peru, Venezuela, Suriname and Bolivia. These countries have large tracts of Amazon rainforest, South American biome and habitats for many Anopheles species that have high potential to be malaria vectors [2,3].

Brazil has the largest number of malaria cases and malaria-related deaths in the Americas, and 15\% of its population lives in at-risk areas, which are concentrated in the states of the Amazon Basin, with an average of 500 thousand notifications per year [4]. The strategies and

\footnotetext{
* Correspondence: pribolla@ibb.unesp.br

'Departamento de Parasitologia, Instituto de Biociências de Botucatu,

Universidade Estadual Paulista, Botucatu, São Paulo, Brasil

Full list of author information is available at the end of the article
}

targets for malaria control include diagnosis, disease treatment and prevention by mosquito control. Therefore, understanding the biology and behaviour of the vector is extreme importance for efficient control of the disease.

The main vectors of malaria in South America are: Anopheles albimanus, Anopheles darlingi and Anopheles nuneztovari in Colombia [5,6]; An. darlingi and Anopheles benarrochi in Peru [7,8]; An. darlingi in Bolivia [9]; $A n$. darlingi, Anopheles marajoara and Anopheles aquasalis in Venezuela [10-12] and An. darling and An. aquasalis in Brasil $[13,14]$. The presence of $A n$. darlingi in the countries cited explains why it is the major target of most studies of malaria vector dynamics in the continent.

Anopheles darlingi is the major vector of malaria in Brazil. There are two main factors that may have contributed to this ability: the species is highly susceptible to the Plasmodium sp. that infect humans [15] and demonstrates anthropophilic behaviour $[2,16]$. With respect to

\section{Biomed Central}


its biology and development, the larvae utilizes commonly water reservoirs close to houses as breeding grounds: lakes, margin rivers, streams and flooding areas, which are shaded or partly shaded, and mats of floating debris and vegetation $[17,18]$. Human presence in the Peruvian Amazon influences the creation of new breeding sites via impoundment and creation of large lakes for fish farming [19].

Concerning seasonality, models differ according to the area and their breeding pattern: riverines areas (dwelling beside a river) with low anthropogenic action show low An. darlingi densities during the dry season, which increase a few months after the beginning of the rainy season, reaching their highest levels at the peak of this season. For inland areas with high anthropogenic action, where there is a greater presence of artificial breeding sites, the water reserve tends to retain its capacity during the dry seasons and the mosquito densities rise to high values by the end of the rainy season, persisting at a high level in the dry season [14,20-22]. Tadei [23] reported that low-lying and flooded areas have numerous breeding sites and high mosquito densities, and the dry and rainy seasons do not have much effect on anopheline populations. Finally, some studies still show that there are no correlations between An. darlingi populations and rainfall, so this result might be a consequence of the known variability in mosquito abundance among localities [11,12].

The periods of biting activity are crepuscular and overnight, with peaks in the early hours of the evening; there may be an extension of this activity during the night, according to the season and to the vector's population density $[3,24,25]$. As for endophilic/exophilic behavior, it is hypothesized that this feature changed because of the introduction of control methods, which consist of the use of indoor insecticides [26]. Early analysis of An. darlingi showed the species to be endophilic, as after feeding on blood, the females rested in the internal structure of the house $[27,28]$. Recent studies show a behavior change, where there was an increased presence of mosquitoes in the peri-domicile, which is located outside the house but close to it $[3,14,25]$. New prophylactic measures are being studied, as is the use of repellents and insecticide impregnated bed nets $[29,30]$.

Various factors that change the habitat and performance of An. darlingi, mainly due to human interventions, have led us to research an intraspecies difference between the populations. Forest degradation, increased housing in the local forest and climate changes are strong influences on Anopheles populations. Therefore, it is necessary to obtain tools to identify and characterize the intraspecies variability in $A n$. darlingi.

For studies with $A n$. darlingi, which has an extensive geographic distribution, it is necessary that the marker chosen provides a degree of polymorphism detectable among individuals. The molecular marker contributes to the understanding of the heterogeneity of the species, clarifying the important information about the vector and its population structure [31,32]. Wide use of mitochondrial DNA (mtDNA) sequencing determines population structure in medical entomology [33-35]. The mitochondrial genome consists of a small, circular molecule with conserved genetic content (only 37 genes) and a simple genomic structure (maternal inheritance, absence of recombination, small or absent intergenic areas, absence of introns, repetitive DNA, pseudogenes and transposable elements) [36]. The molecule evolves about 5-10 times faster than the nuclear genes do [36-38]. Constantly used in studies with Aedes aegypti [39-41], this marker showed satisfactory results with $A n$. darlingi [42], which were high polymorphism and similar indexes of nucleotide diversity from other mitochondrial genes for neotropical anophelines [43,44].

The state of Acre is situated in the Amazon basin. In 2008, 9,410 malaria notifications were reported, with 8,595 occurring in rural settlements [4]. The study site of this paper, the municipality of Acrelândia, represents a risk area [45] and is the subject of several publications on the Anopheles sp. [46-48]. The aim of this study was to verify the behavior, distribution and population structure of the major vector of the region, An. darlingi. The area is subject to continually gradual changes of the geographic space, and this fact highly influences An. darlingi dynamics.

\section{Methods \\ Study Area}

Acrelândia, $122 \mathrm{~km}$ from Rio Branco, is a small town with approximately 12,000 inhabitants located in the western state of Acre (Figure 1). The area has a history of urbanization like other regions of the Amazon biome, starting with the Rubber Boom in the early twentieth century, followed by other extractive activities such as the mining and lumber industries. Currently, agriculture is the main factor responsible for the continued deforestation.

The Ramal do Granada (Brazilian Federal Highway 364) is located in rural area of Acrelândia, and belongs to the Pedro Peixoto Agricultural Settlement Project, a Settlement Program Directed (Programa de Assentamento Dirigido - PAD) responsible for subdivision and land distribution in various uninhabited regions of the Brazil. The Ramal do Granada (Figure 1) has a linear extension of $30 \mathrm{~km}$ from point 0 (BR 364-highway) and includes households along an unpaved road, with the economy based on agriculture, mainly with livestock. The number of homes and the degree of deforestation vary according to the position along the road: the proportion of degradation that correlates with human actions can be assessed 


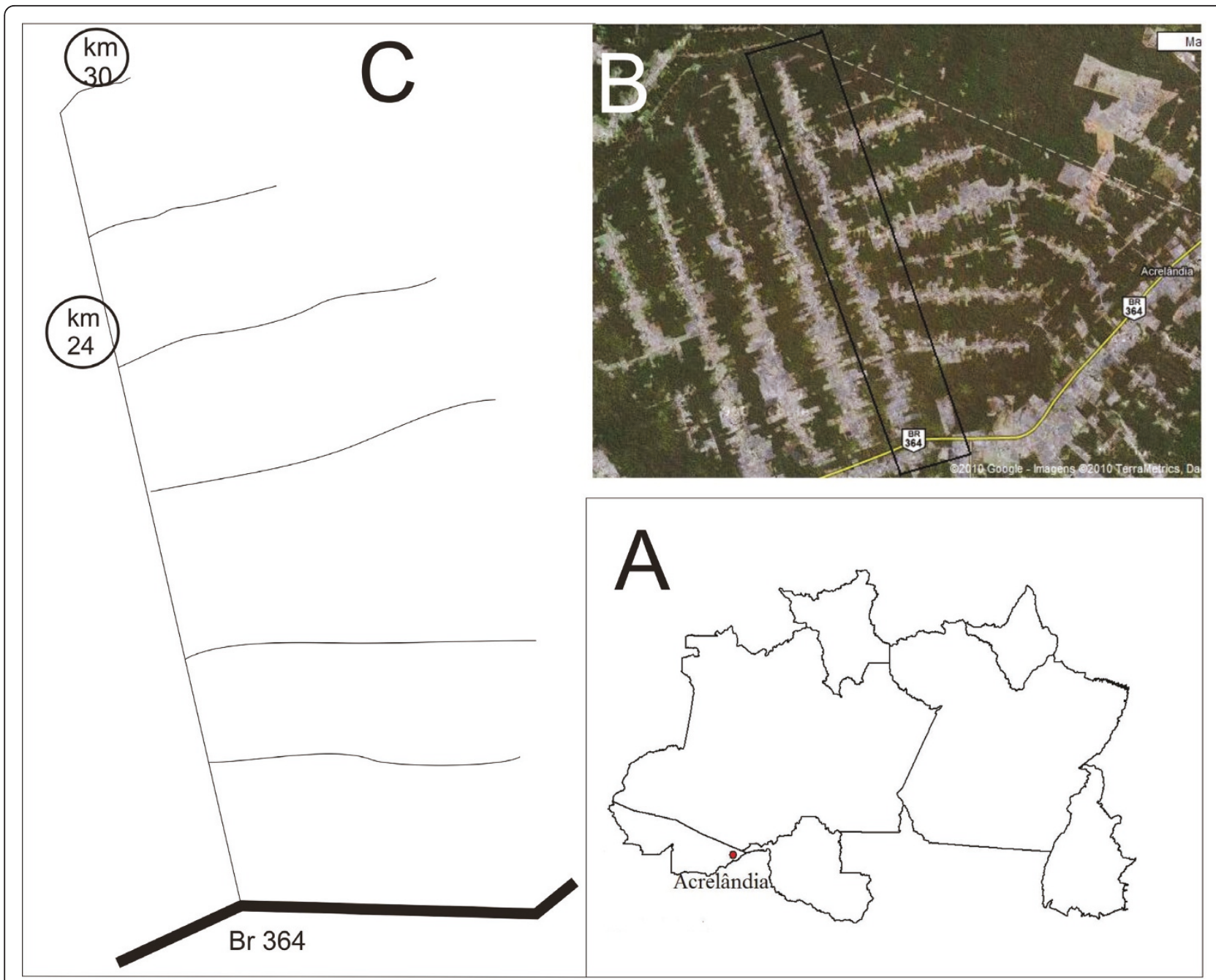

Figure 1 Study Area. A: Acrelândia, in northern Brazil. B: satellite image from "Ramal do Granada" ( ${ }^{(} 2010$ Google-Images ${ }^{\circ} 2010$ TerraMetrics, Nasa, Dados cartográficos ${ }^{\circ} 2010$ Maplink). C: "Ramal do Granada" with the sampling sites km 24, km 30 and BR 364 (Point 0).

via the linear distance from point 0 . The tendency is this; the farther from point 0 , the lower the number of residents and the level of deforestation.

Considering this information, two sampling sites for Anopheles adult were selected from Ramal do Granada (Figure 1): km 24 (455ft; S09 44.542'; WO67 ${ }^{\circ} 07.212^{\prime}$ ) and km 30 (421 ft; S 0941,247'; WO6707,692). The km 24 represents the area with more degradation and higher numbers of houses, and $\mathrm{km} 30$ represents the area with more recent occupation. Both sites have the following: streams and water reserves; flooded areas; similar structure of the houses; and the presence of riparian forests and pasture near the residences (Figure 2).

\section{Mosquito collection}

Each mosquito collection consisted of indoor and outdoor capture, composed of three consecutive days; 3 hour captures at first and second day $(\mathrm{km} 24$ and $\mathrm{km} 30$ respectively) and 12-hour capture at the third day (only $\mathrm{km} \mathrm{30).} \mathrm{The} \mathrm{3-hours} \mathrm{capture} \mathrm{occurred} \mathrm{between} \mathrm{6:00} \mathrm{pm}$ and 9:00 pm and the 12-hours capture between 6:00 pm and 6:00 am. The interval between 6:00 pm and 9:00 pm for the 3-hour capture was decided upon by consulting the literature, which reported the twilight behaviour of An. darlingi [3,24,25,49].

The weather conditions specific to each collection day are listed in Table 1. Temperature and $\mathrm{RAH}$ are the average values from two digital thermo-hydrometers ITHT2000 (Instrutemp), located indoor and outdoor capture. The rainfall values were obtained with the State Civil Defense of Acre. Moon phases were collected in http:// www.moon-phases.net and the climatic condition were noted during capture day. There was a concern with the choices of the capture day, avoid events that change the biting activity (rain, fogs, full moon), establishing a pattern of weather conditions for the collections. 

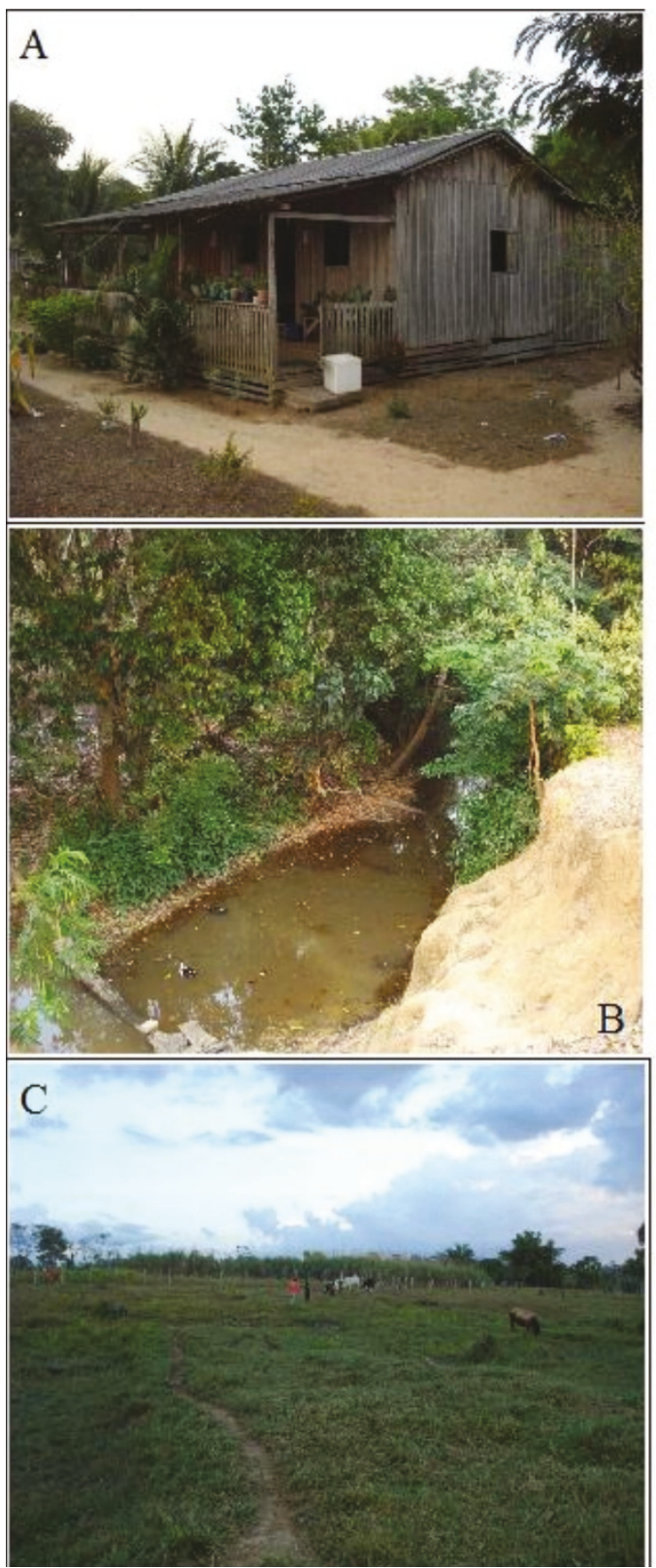
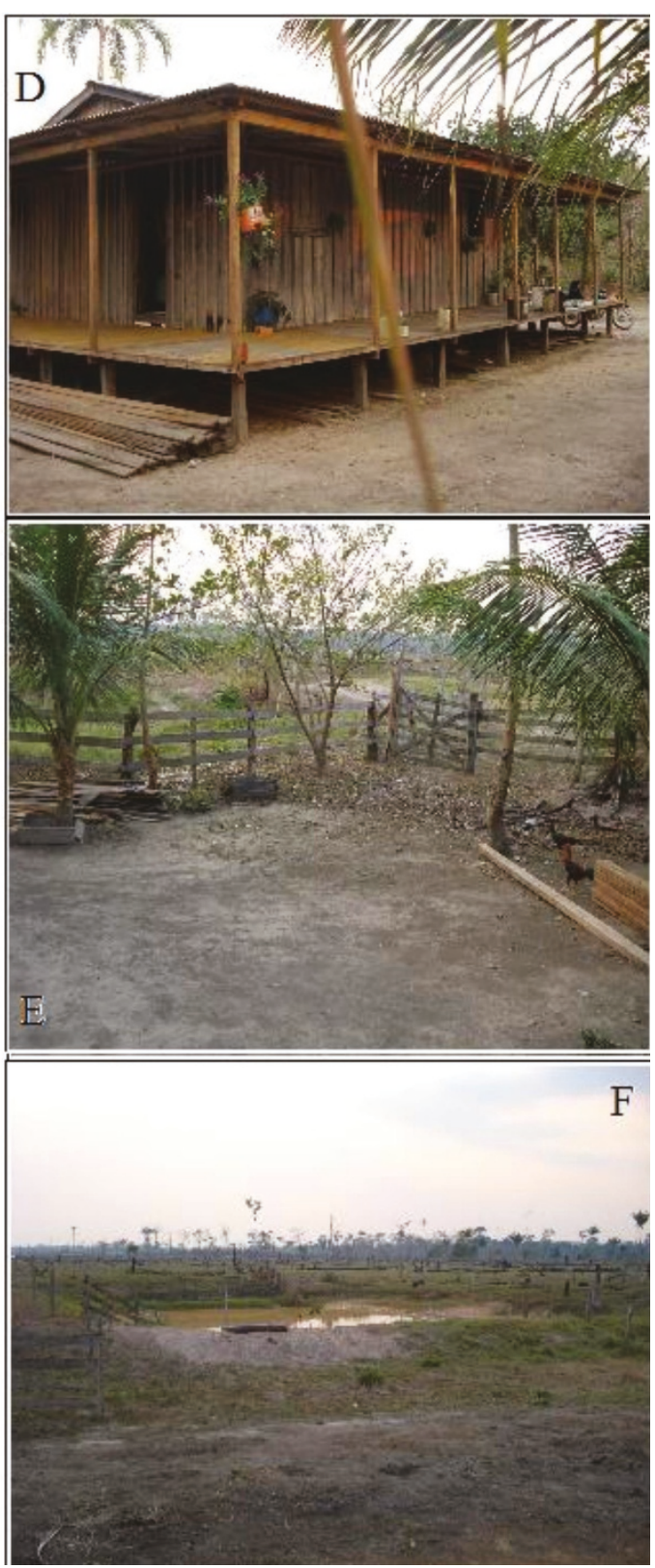

Figure 2 Collection points. Km 24 (A: indoor capture, B; outdoor capture, C: pasture behind the house) and Km 30 (D: indoor capture, E; outdoor capture, F: pasture behind the house).

The mosquitoes was captured using human bait, performed by the own authors. Following the seasonal variation of rainfall, five collections were conducted over ten months: May, July, September and November 2008 and February 2009. Mosquitoes were identified using a key species of the subgenus of Nyssorhynchus [50] and preserved in 70\% isopropyl alcohol.

\section{Extraction, Amplification and Purification of mtDNA}

For the extraction of mtDNA from An. darlingi, Chelex ${ }^{\circledR}$ Molecular Biology Grade Resin (Bio-Rad Laboratories) was used. DNA was extracted from mosquitoes individually, following the manufacturer's recommendations. The extracted DNA was quantified using an ND-1000 (Nanodrop) spectrophotometer and its purity was also checked.

Amplification reactions were conducted according to the protocol of Gorrochotegui-Escalante with modifications [51]. Amplification was done in a final volume of $40 \mathrm{ul}$, using 2 ul of the DNA sample, $20 \mathrm{uL}$ Gotaq Colorless Master Mix (Promega), $12 \mathrm{uL}$ ultrapure water (Aster) and $6 \mathrm{uL}$ of oligonucleotides specific for the ND4 gene: $3 \mathrm{uL}$ of ND4-F (5'-TGATTGCCTAAGGCTCATGT-3') and 3uL 
Table 1 Weather Conditions at the collection points (km 24 and km 30) during the work period

\begin{tabular}{|c|c|c|c|c|c|c|c|}
\hline Month & Capture day & Temperature & $\left(\mathrm{C}^{\circ}\right)$ & RAH (\%) & Rainfall (mm) & Moon Phases & Climatic Condition \\
\hline \multirow[t]{3}{*}{ May/08 } & $3 \mathrm{~h}-\mathrm{km} 24$ & 24.4 & & 85 & 0 & New Moon & Clean \\
\hline & 3h-km30 & 27.3 & & 79 & 0 & Waxing Crescent & Clean \\
\hline & $12 \mathrm{~h}-\mathrm{km} 30$ & 23.1 & & 90 & 0 & Waxing Crescent & Clean \\
\hline \multirow[t]{3}{*}{ July/08 } & $3 \mathrm{~h}-\mathrm{km} 24$ & 25.3 & & 80 & 0 & Waxing Crescent & Clean \\
\hline & 3h-km30 & 24.8 & & 68 & 4.9 & Waxing Crescent & Partly cloudy \\
\hline & $12 \mathrm{~h}-\mathrm{km} 30$ & 22.7 & & 80 & 0 & First Quarter & Partly cloudy \\
\hline \multirow[t]{3}{*}{ Sept/08 } & $3 \mathrm{~h}-\mathrm{km} 24$ & 27.2 & & 70 & 0 & Waxing Crescent & Clean \\
\hline & 3h-km30 & 28.8 & & 57 & 0 & Waxing Crescent & Clean \\
\hline & $12 \mathrm{~h}-\mathrm{km} 30$ & 25.6 & & 81 & 0 & Waxing Crescent & Clean \\
\hline \multirow[t]{3}{*}{ Nov/08 } & $3 \mathrm{~h}-\mathrm{km} 24$ & 23.2 & & 97 & 7.2 & Waning Crescent & Partly cloudy \\
\hline & 3h-km30 & 28.1 & & 79 & 0 & Waning Crescent & Partly cloudy \\
\hline & $12 \mathrm{~h}-\mathrm{km} 30$ & 24.5 & & 95 & 8.6 & New Moon & Cloudy \\
\hline \multirow[t]{3}{*}{ Feb/09 } & $3 h-k m 24$ & 28.9 & & 84 & 0 & Waxing Crescent & Partly cloudy \\
\hline & 3h-km30 & 28.7 & & 74 & 25.3 & Waxing Crescent & Partly cloudy \\
\hline & $12 \mathrm{~h}-\mathrm{km} 30$ & 26.4 & & 88 & 83.5 & First Quarter & Cloudy \\
\hline
\end{tabular}

Temperature and RAH; average values from two thermo-hydrometers, located indoor and outdoor capture; Rainfall: State Civil Defense of Acre; Moon Phases: http://www.moon-phases.net; Climatic Condition: noted during capture day.

of ND4-R (5'-TTCGGCTTCCTAGTCGTTCAT-3') (Invitrogen). Amplification reactions were performed in a Whatman Biometra ( $\mathrm{T}$ Gradient) thermocycler with temperature cycles of: three cycles of $94^{\circ} \mathrm{C} / 2 \mathrm{~min}, 37^{\circ} \mathrm{C} / 2 \mathrm{~min}$, and $72^{\circ} \mathrm{C} / 1 \mathrm{~min}$, followed by 35 cycles of $94^{\circ} \mathrm{C} / 30 \mathrm{~s}, 50^{\circ} \mathrm{C} /$ $30 \mathrm{~s}$, and $72^{\circ} \mathrm{C} / 1 \mathrm{~min}$, with a final extension cycle of $72^{\circ} \mathrm{C} /$ 5 min. Polymerase chain reaction (PCR) products were subjected to electrophoresis through an agarose [52]. The specific region of the ND4 gene that was amplified corresponds to nucleotides 8.519-8.880 in Aedes albopctus [GenBank:AY072044], and has been used in other publications by our research group $[40,42]$.

PCR products were purified using Montage PCR Centrifugal Filter Devices (Millipore), following the manufacturer's recommendations.

\section{Sequencing mtDNA and Data Analysis}

The purified PCR products and an aliquot of the oligonucleotides specific for the ND4 gene $(10 \mathrm{pmol} / \mathrm{L})$ were sent to the bio-molecular company Macrogen (Seoul, South Korea). Sequencing was conducted under BigDye Terminator Cycling Conditions. The reaction products were purified using ethanol precipitation and run using the Automatic Sequencer 3730XL. ND4 gene sequences were analysed, as was the reaction efficiency of sequencing. A fragment of 286 base pairs was used to compare the sequences and for further analysis. These sequences were aligned using Clustal W [53], and misaligned nucleotides were manually adjusted. The program MEGA [54] was used to perform phylogenetic and molecular analysis. Distance (Neighbor Joining, NJ) and parsimony methods were used to construct phylogenetic trees [55] using the Kimura 2 parameters distance [56]. Nucleotide sequences and haplotype frequencies were calculated using DnaSP version 3.5 [57]. Genetic analysis of population differentiation, haplotype diversity index, and nucleotide diversity were calculated with Arlequin 3.0 software [58] and a haplotype map was constructed by TCS, version 1.12 .

\section{Results}

\section{Mosquito Collections}

A total of 3,486 mosquitoes were collected, with 2,982 (85.5\%) being An. darlingi. Others Anopheles species were also collected: Anopheles deaneorum, Anopheles rangeli, Anopheles albitarsis, Anopheles braziliensis, Anopheles triannulatus and Anopheles argyritarsis. Table 2 depicts the distribution of $A n$. darlingi, only for the 3-hour capture. The collections show significant quantitative differences between the sites: km 24 showed a lower density of $A n$. darlingi compared to $30 \mathrm{~km}$, and the outdoor capture had the major number of mosquitoes collected. The low value of the sample at $\mathrm{km} \mathrm{24}$, compared to $30 \mathrm{~km}$, was observed for all of the months.

Table 2 An. darlingi densities during the 3-hour captures.

\begin{tabular}{ccccc}
\hline & \multicolumn{2}{c}{ Km $\mathbf{2 4}$} & \multicolumn{2}{c}{ Km 30} \\
Month & Indoor & Outdoor & Indoor & Outdoor \\
\hline May/2008 & $4(1.3)$ & $1(0.3)$ & $66(22)$ & $102(34)$ \\
July/2008 & 0 & $5(1.7)$ & $2(0.7)$ & $145(48.3)$ \\
September/2008 & 0 & $5(1.7)$ & 0 & $7(2.3)$ \\
November/2008 & 0 & $1(0.3)$ & $8(2.7)$ & $37(12.3)$ \\
February/2009 & $2(0.7)$ & $3(1)$ & $95(31.7)$ & $399(133)$ \\
\hline Total & 6 & 15 & 171 & 690 \\
\hline
\end{tabular}

Total number collected per location (number of mosquitoes/person/hour). 
The 12-hour captures shows a higher concentration of $A n$. darlingi at the first part of the night, with biting activity starting at sunset. Figure 3 shows a pattern of biting activity that alternates according the population density. May 2008 indoor capture displayed a classic bimodal cycle. For the May, July, September and November outdoor captures, the occurrence is predominantly in the first part of the night. February 2009, month with the highest population density, registered biting activity until the early morning hours in both captures. 1,899 An. darlingi were collected in the twelvehour capture, with $73.6 \%$ being outdoor captures.

\section{Seasonal Variation}

Figure 4 represents the distribution of the anopheline mosquitoes relative to precipitation and temperature monthly average. Each month's collection represents the total number of $A n$. darlingi captured from both sites in

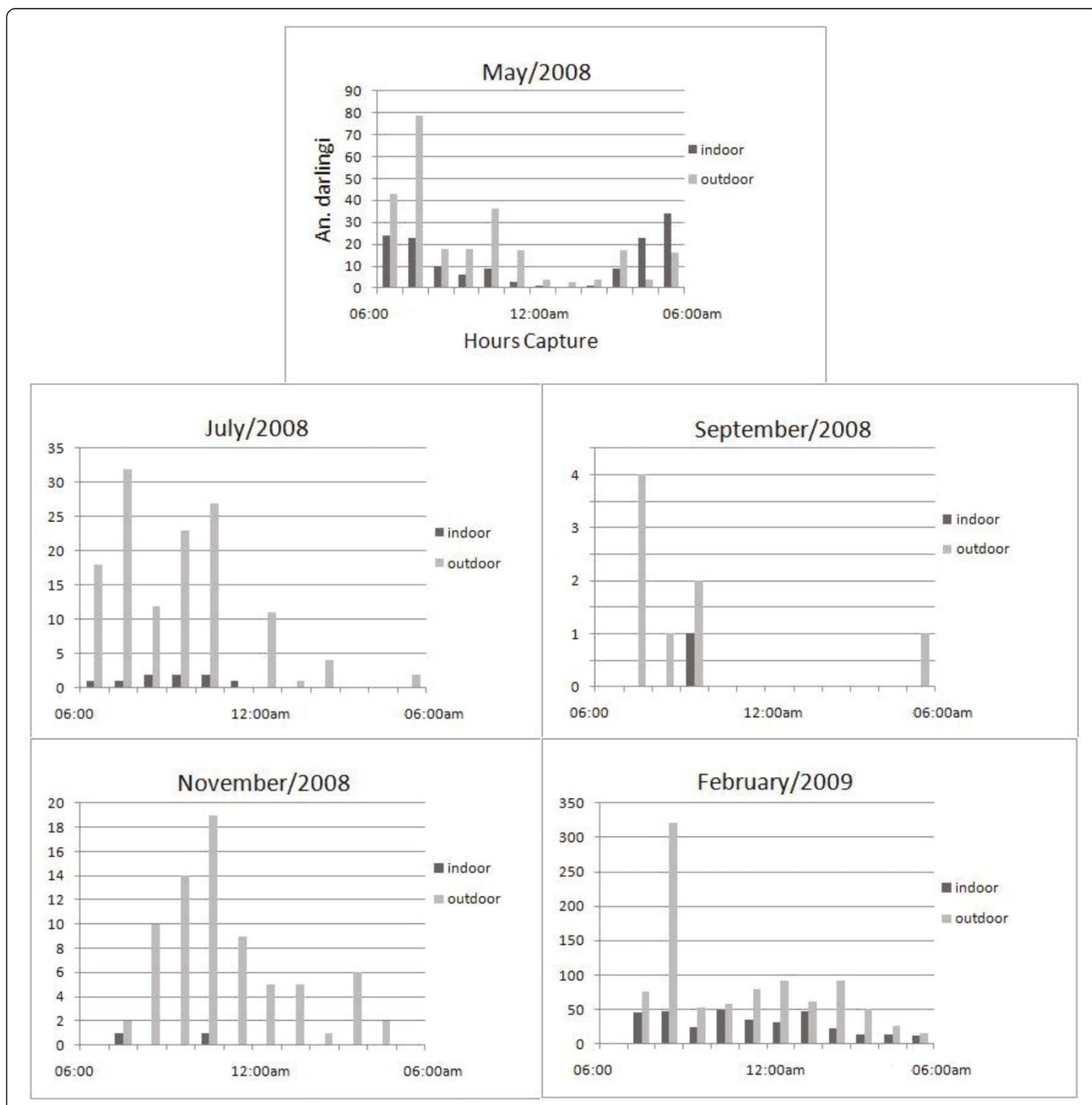

Figure 3 An. darlingi 12-hour capture. Biting activity of An. darling in 12-hour capture at km 30. 

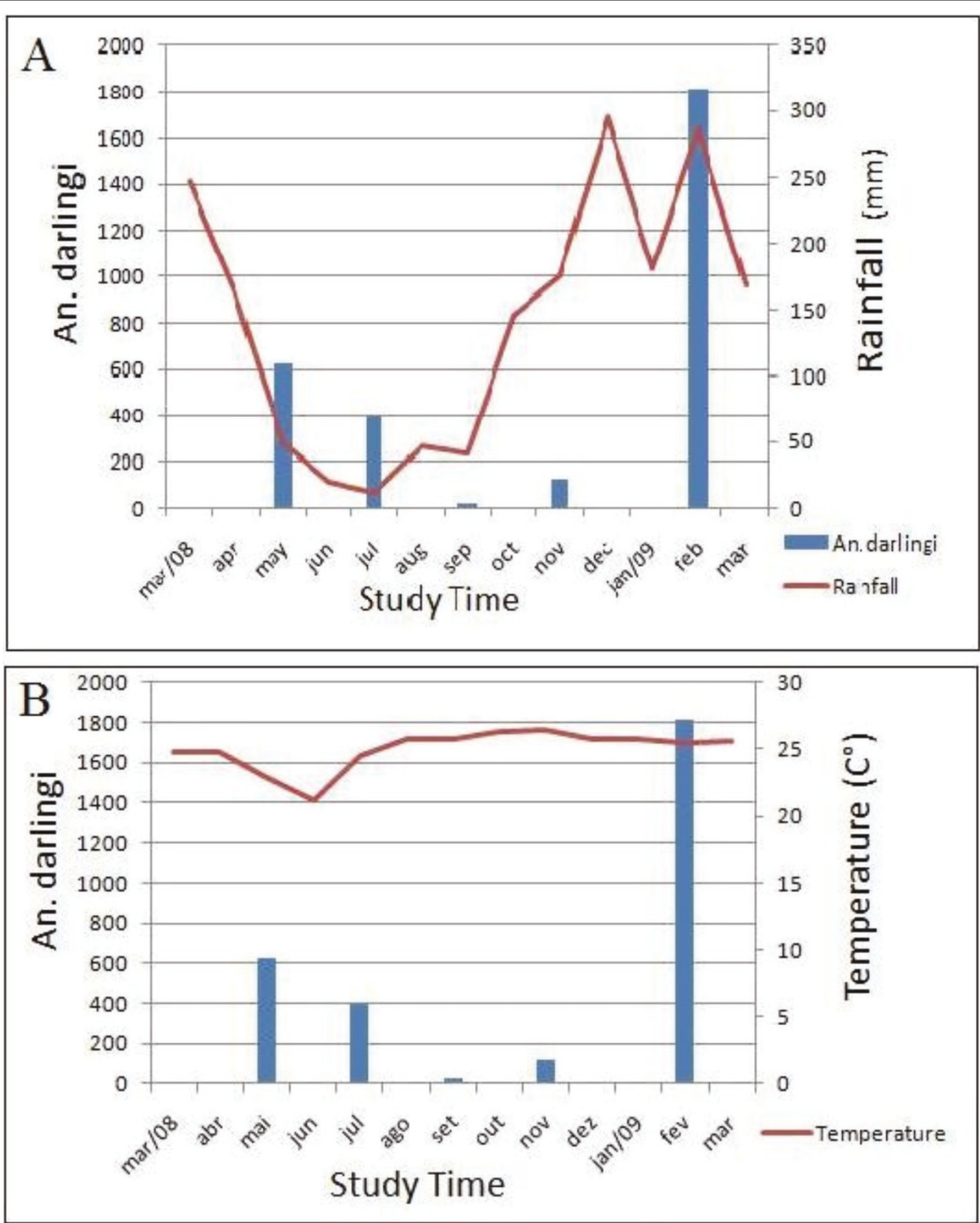

Figure 4 An. darlingi seasonal density; rainfall (A) and temperature (B). The values correspond the monthly averages.

three days (3-hour capture at $\mathrm{km} \mathrm{24,3-hour} \mathrm{capture} \mathrm{at}$ $\mathrm{km} 30$ and 12-hour capture) and shows the variation of mosquitoes according to the study period. It is important to note this change; May to July 2008 there was an observed decrease of precipitation, which followed the decrease of An. darlingi; opening of the dry season and diminution of temperature. September 2008 is the month that best illustrates how the mosquito density decreases during the dry season.

With the increase in precipitation and the rise in temperature marking the beginning of the rainy season. November 2008 reflects this transition with a significant increase of An. darlingi in relation to September. Lastly, February 2009, two months after the high record for 
rain precipitation, showed the largest number of mosquitoes, representing approximately $61 \%$ of the entire collection.

\section{Sequencing analysis of mtDNA}

One hundred ten mosquitoes were sequenced: 30 from July, 12 from September, 33 from November and 35 from February. Only An. darlingi indoor and outdoor from $\mathrm{km} \mathrm{30,} \mathrm{the} \mathrm{collection} \mathrm{site} \mathrm{that} \mathrm{shows} \mathrm{higher} \mathrm{den-}$ sity, were chosen, thereby obtaining significant values for the seasonal variation of species. The alignment of these sequences showed the presence of 20 polymorphic sites representing 18 different haplotypes. The populations showed an index of nucleotide diversity of $\pi=$ 0.0127 , and a haplotype diversity $\mathrm{Hd}=0.895$. A total of 20 mutations were identified, with 16 synonymous mutations.

Analysis of sequences and the map of haplotypes by TCS (Figure 5), indicate the occurrence of two major groups, separated by two mutational steps. Table 3 aggregates the sazonal variation of haplotypes with samples numbers, between July, 2008 and February, 2009. There is a difference between the haplotype frequencies in each month: five exclusive haplotypes in November 2008 (H3, H8, H16, H17 and H18) are not found in the collection for February, 2009, the month that had the highest density of $A n$. darling. The haplotypes with the highest numbers of mosquitoes (H4, H5, H9, H11 and H12) are present in all months of collection, except H6, with only six samples. September, 2008, the month with the lowest density and all An. darlingi collected were analyzed, presented seven haplotypes. Six of these are found in the previous month and remained in the

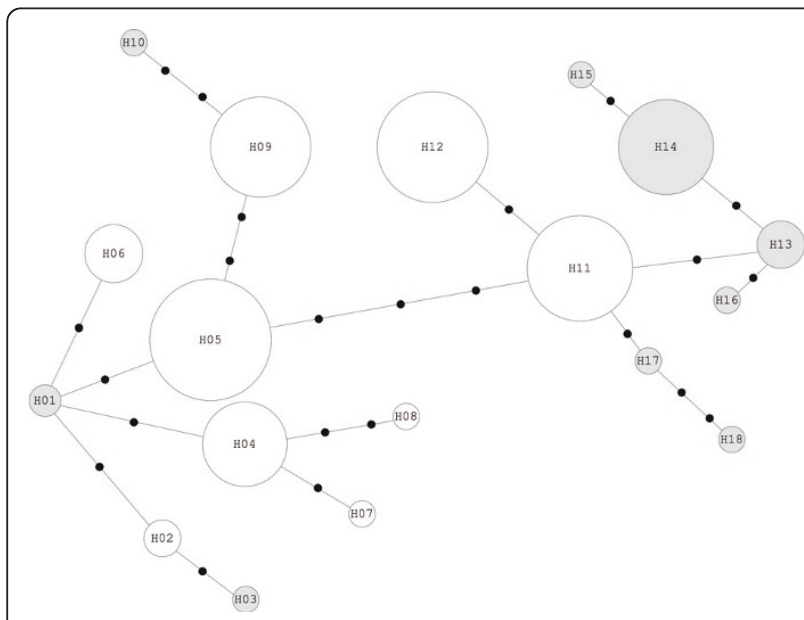

Figure 5 Statistical parsimony network. 18 haplotypes of An. darlingi populations for ND4 mitochondrial fragments. Black dots along the lines indicate mutational steps between haplotypes (unrepresented in the sample). The size of the sphere is

proportional to the number of individuals carrying the haplotype. population until February. Pair-a-pair Fst comparisons between populations (Table 4) shows that November and February (Fst $=0,05, \mathrm{P}<0,01)$ is the only significant result.

\section{Discussion}

The results presented here show variations in the density of mosquitoes between both sampling sites, showing a relationship between local anophelines and degraded natural areas. These changes result in several consequences for the mosquitoes fauna, establishing different models of population dynamics of malaria vectors. Some studies shows that modifications in natural environments promote succession of faunas and changes the species adaptability in urban landscapes [59-61] and these are important factors in the epidemiology of tropical diseases, being that settlement areas have growth in the Amazon basin [62].

The species diversity and the total amount of anophelines show $\mathrm{km} 30$ to have major abundance and population density, while $\mathrm{km} 24$ reports low density. The choice of these two sampling sites in Ramal do Granada was justified by similar forms of human occupation, but with different degrees of deforestation and human actions. The landscape features of $\mathrm{km} 30$ are newly deforested areas with recent occupation, with a great presence of burn forest residues in pastures, and significant coverage of the Amazon rainforest. The distributions of houses in this site are similar: all are close to the road, however distant from each other, as a consequence of a lower number of residences. Unlike at $\mathrm{km} \mathrm{30}$, the $\mathrm{km} 24$ location has residences that are more aggregated and that have been occupied for longer. Collections and reserves of water are similar in both sites, with streams and artificial ponds used for raising cattle. Thus, in comparing the five 3-hour captures, it appears that differences between both sampling sites influence the development of the respective Anopheles population. The forest is directly related to the biology of $A n$. darlingi, and this difference is linked with the ecology of the species in the environment of each site $[21,63]$. Studies in rural settlements in Rondônia reported, using the degree of urbanization, environment and economic activity, highest malaria risk in areas are around and next to forests [64].

The influence of human actions on populations of $A n$. darlingi in Ramal do Granada shows that a significant level of degradation decreases the presence of this vector. The area of the most recent occupation and closer to undisturbed forest, the $\mathrm{km} \mathrm{30}$, shows an increase in the abundance of anopheline mosquitoes compared to $\mathrm{km} 24$. Epidemiological data of malaria in Ramal do Granada indicate that $\mathrm{km} 30$ is the locality with the most susceptible hosts and the highest incidence rate of disease, associating the observations that newcomers tend to settle in 
Table 3 Temporal variation of haplotypes

\begin{tabular}{|c|c|c|c|c|c|}
\hline Month/Haplotype & Jul/08 & Sep/08 & Nov/08 & Feb/09 & number of individuals \\
\hline $\mathrm{H} 1$ & $X X X X X$ & & & $X X X X X$ & 2 \\
\hline $\mathrm{H} 2$ & & & & $X X X X X$ & 3 \\
\hline $\mathrm{H} 3$ & & & $X X X X X$ & & 1 \\
\hline $\mathrm{H} 4$ & $X X X X X$ & $X X X X X$ & $X X X X X$ & & 11 \\
\hline $\mathrm{H} 5$ & $X X X X X$ & $X X X X X$ & $X X X X X$ & $X X X X X$ & 18 \\
\hline $\mathrm{H} 6$ & $X X X X X$ & $X X X X X$ & $X X X X X$ & $X X X X X$ & 6 \\
\hline $\mathrm{H} 7$ & & & & $X X X X X$ & 1 \\
\hline $\mathrm{H} 8$ & & & $X X X X X$ & & 1 \\
\hline $\mathrm{H} 9$ & $X X X X X$ & $X X X X X$ & $X X X X X$ & $X X X X X$ & 14 \\
\hline $\mathrm{H} 10$ & $X X X X X$ & & & & 1 \\
\hline $\mathrm{H} 11$ & $X X X X X$ & $X X X X X$ & $X X X X X$ & $X X X X X$ & 15 \\
\hline $\mathrm{H} 12$ & $X X X X X$ & $X X X X X$ & $X X X X X$ & $X X X X X$ & 16 \\
\hline $\mathrm{H} 13$ & & $X X X X X$ & & & 4 \\
\hline $\mathrm{H} 14$ & $X X X X X$ & & $X X X X X$ & $X X X X X$ & 13 \\
\hline $\mathrm{H} 15$ & $X X X X X$ & & & & 1 \\
\hline $\mathrm{H} 16$ & & & $X X X X X$ & & 1 \\
\hline $\mathrm{H} 17$ & & & $X X X X X$ & & 1 \\
\hline $\mathrm{H} 18$ & & & $X X X X X$ & & 1 \\
\hline Exclusive haplotipe & 1 & 1 & 5 & 2 & \\
\hline
\end{tabular}

Cells with "XXXXX" represent the presence of the specific haplotype at that period.

forest fringes and tend to have no malaria immunity $[65,66]$. Malaria prevalence in Granada is similar to that described in peri-urban and rural populations in the State of Rondônia; this area consists predominantly of migrants who settled there at least a decade previously [67].

An. darlingi depends on the regions with forests for their larval and adult survivorship, and profound changes in their habitat may restrict their presence $[68,69]$. Environmental analysis and characterization of the breeding sites of both sampling sites has produced more data for this argument [19]. However, differences in the vectors' densities along the same line of a rural settlement can be affirmed analyzing these results; this is an effective tool to indicate where case monitoring and vector control should be directed [70].

The night biting activity seen in the 12-hour capture reports the trend observed in other An. darlingi studies in Amazon Basin; beginning at twilight, with peaks concentrated in the first part of the night $[3,8]$. May and July, the biting activity starts at 6:00 pm, while the others months starts after one hour (7:00 pm). The main variations verified during each sampling month were related to anopheline density; in the months with higher densities, the presence of An. darlingi persisted through the second part of the night until dawn, as shown in February. The outdoor capture in May show two peaks in the first part of the night, and indoor capture displays a bimodal pattern. The presence of more than one peak during the twilight hours is reported in outdoor capture in July, transition between the rainy and dry season, and outdoor capture in November, transition between the dry to rainy season. July density concentrated in the first part of the night, and November peaked later $(11: 00 \mathrm{pm})$, with activity until 5:00 pm. This variations showed that though An. darlingi is most active at twilight, a prolongation of biting activity is common outside the standard time range, which increases the vector capacity of the species. The 12-hour capture also showed a high difference between indoor and outdoor mosquitoes.

Table 4 F-Statistics based on pairwise estimates of ND4 haplotype frequencies

\begin{tabular}{ccccc}
\hline Month & July/2008 & September/2008 & November/2008 & February/2009 \\
\hline July/2008 & 0.00000 & - & - & - \\
September/2008 & -0.01554 & 0.00000 & - & - \\
November/2008 & -0.00756 & 0.00131 & 0.00000 & - \\
February/2009 & 0.00921 & -0.02740 & $0.04663^{*}$ & 0.00000 \\
\hline
\end{tabular}


The seasonality data is linked with the presence and types of breeding sites in the region, and is consequence of the extent of landscape changes. Analyzing Figure 4, indicates that the density of An. darlingi from May, 2008 to July, 2008 is in decline, showing a probable relationship with the decrease of rainfall and the beginning of dry season [71]. One can speculate that the decrease in precipitation left the breeding sites still able to support breeding, but not enough to maintain high densities of the vector. This prominent decrease in rain level was reflected in minimal rates for mosquito populations in September, 2008. With the transition to the rainy season, there was a considerable density increase in November, 2008, followed by a large growth in February 2009, 61\% of the total An. darlingi collected during the all study. Similar data in two villages located in Maroni River (Suriname and French Guiana frontier) shows after heavy rainfall providing temporary breeding places for the $A$. darlingi, which explains the rapid increase in population densities after the rain [30]. It is also important to mention that the numbers of An. darlingi listed in Figure 4 are the three captures aggregate (3-hour capture km 24, 3-hour capture $\mathrm{km} 30$ and 12-hour capture), so that a greater proportion of these mosquitoes belong $\mathrm{km} 30$. Therefore, we can assume that the natural breeding site's capacity is maximized during the rainy season [14]. However, to support this hypothesis, there is the need to perform a larval study on the breeding sites in the area and to correlate this with abundance of $A n$. darlingi and river levels [12].

The choice of samples for the molecular analysis was based on two criteria: comparison between indoor and outdoor mosquitoes, and variability and seasonal distribution of haplotypes. For this, a sample selection was made, covering a significant portion of $A n$. darlingi of all times in 12-hours captures. In the final methodology, were not processed $A$. darlingi from $\mathrm{km} 24$ sampling site and from May, 2008. No significant variability was observed between the indoor and outdoor populations ( $\mathrm{P}=0.265)$, despite the fact that Forattini [72] postulated that exophilic and endophilic behavior could be a possible characteristic of distinct populations. Both collections, 3-hour and 12-hour capture, showed a prevalence of outdoor mosquitoes. The Ramal do Granada, as in other regions of the Amazon rainforest, has utilized control measures for malaria vectors, consisting of the use of indoor insecticides [26]. House-spraying by SESACRE (Acre State Secretariat of Health and Sanitation) is common; periodically, at three month intervals and immediately after a positive case is notified (called Bloqueio). Spraying occurs in the homes of patients, ridding the inside of their residence of the vectors. Quantitative data show that there is a difference between the populations of $A n$. darlingi that feed in the home and those outside, as a consequence of the constant use of house spraying. However, we can observe a significant increase in biting activity in the intra-domicile region during the rainy season.

The variability in seasonal distribution of haplotypes shows monthly changes in population structure of $A n$. darlingi. Were defined as exclusive haplotypes the strains found only one month of the study, and common haplotype found in two months or more. The haplotypes reported are representative samples from 12-hour capture; July, September, November 2008 and February 2009. Analyzing Figure 5 and Table 3, the two major groups, separated by two mutational steps, have the same proportion of haplotypes exclusive and common. The first group, $\mathrm{H} 1$ to H10 (58 samples) have four common haplotypes (51 samples) and six exclusive haplotypes (7 samples). The second group, H11 to H18 (52 samples), have three common haplotypes (44 samples) and five exclusive haplotypes (8 samples). November, transition to the rainy season and growing of $A n$. darlingi population, have the greatest haplotype variability compared to other months of study.

ND4 polymorphism shows a intra-population variation regulated by environmental (rainfall, temperature, weather conditions) and anthropic factors (fogs, insecticides, forrest degradation). The Fst is significant only between November and February and reveals two distinct moments of the $A n$. darlingi; the transition to the rains, having a population growth and filling of vacant niches in November and the population reaching the high density in February. This shows variation during population dynamics in transition to the rains, however suggest no shifting population structural; 84 samples from exclusive haplotypes found in July are also reported in February, which represents $76.36 \%$ of the total samples. The seasonal distribution of haplotypes shows no change in the population of An. darlingi in Ramal do Granada.

This feature of the local anopheline population is relevant because frequent changes of the landscape can affect population dynamics, allowing for the spread of groups of genes related to malaria transmission, which enhance the mosquitoes' status as vectors [31]. It is also important to mention that the Plasmodium vivax populations circulating in the Ramal do Granada are extraordinarily diverse, factor that contributes to malaria transmission in endemic regions [73].

\section{Conclusions}

At the outset, $A n$. darlingi is the major vector found in this study area. Their distribution is related to forests areas, and their abundance occurs in areas of recent colonization. An. darlingi behavior was similar to that described in the scientific literature: activity at twilight that persisted until halfway through the night and was exophilic. Prolongation of the biting activity was reported 
in months with higher densities. Variation of the population size is related to rainfall, and is a consequence of the anthropogenic factors in the region. A high density of species was reported during the rainy season. Sequencing analysis of the mitochondrial gene ND4 shows that the seasonal variability haplotype indicates a stable population, without the insertion of new strains in transition between the dry and rainy seasons.

\section{Acknowledgements}

Marcelo Urbano Ferreira (ICB-USP), Simone Ladeia Andrade (DMT-IOCRUZ), Maria Anice Mureb Sallum (FSP-USP), Aline Fernandes Angella and Karina dos Santos Paduan (IBB-UNESP) and FUNASA from Acrelândia. Rainfall and temperature data provided by Carlos Cordeiro (INPE-AC). Supported by FAPESP.

\section{Author details}

'Departamento de Parasitologia, Instituto de Biociências de Botucatu, Universidade Estadual Paulista, Botucatu, São Paulo, Brasil. ${ }^{2}$ Instituto de Pesquisa em Patologias Tropicais, Porto Velho, RO, Brasil.

\section{Authors' contributions}

PRM: prepared the initial project, participated in the collections and travel to study area, development and molecular analysis of samples and drafted the manuscript. LHSG: participated in the collections and travel to study area, identification and preservation of material. RBC: participated in the collections and travel to study area, identification and preservation of material. PEMR: prepared the initial project, participated in the collections and travel to study area and molecular data analysis, as well as helped to draft the manuscript. All authors read and approved the final manuscript.

Received: 9 September 2010 Accepted: 24 June 2011

Published: 24 June 2011

\section{References}

1. WHO: WorldMalariaReport2010. [http://www.who.int/malaria/ world_malaria_report_2010/worldmalariareport2010.pdf].

2. Deane LM: Malaria vectors in Brazil. Mem Inst Oswaldo Cruz 1986, 81(Suppl 2):5-14.

3. Lourenço-de-Oliveira R, Guimarães AEG, Arlé M, Silva TF, Castro MG, Motta MA, Deane LM: Anopheles species, some of their habits and relation to malaria in endemics areas of rondonia state, amazon region of Brazil. Mem Inst Oswaldo Cruz 1989, 84(4):501-504.

4. Ministério da Saúde: Situação epidemiológica da Malária no Brasil 2008. [http://portal.saude.gov.br/portal/arquivos/pdf/folder_malaria_2008_final.pdf].

5. Olano VA, Brochero HL, Sàenz R, Quiñones ML, Molina JA: Mapas preliminares de la distribución de especies de Anopheles vectores de Malaria en Colombia. Inf Quinc Epidemiol 2001, 5:339-46.

6. Zapata MA, Cienfuegos AV, Quirós Ol, Quiñones ML, Luckhart S, Correa MM: Discrimination of seven Anopheles species from San Pedro de Urabá, Antioquia, Colombia, by polymerase chain reaction-restriction fragment length polymorphism analysis of its sequences. Am J Trop Med Hyg 2007, 77(1):67-72.

7. Schoeler GB, Flores-Mendoza C, Fernández R, Davila JR, Zyzak M: Geographical distribution of Anopheles darlingi in the Amazon Basin region of Peru. Journal Am Mos Con Assoc 2003, 19(4):286-296.

8. Turell JM, Sardelis MR, Jones JW, Watts DM, Fernandez R, Carbajal F, Pecor JE, Klein TA: Seasonal distribution, biology, and human attraction patterns of mosquitoes (Diptera: Culicidae) in a rural village and adjacent forested site near Iquitos, Peru. J Med Entomol 2008, 45(6):1165-1172.

9. Harris AF, Matias-Arnéz A, Hill N: Biting time of Anopheles darlingi in the bolivian Amazon and implications for control of malaria. Trans of the Royal Society of Trop Med and Hyg 2006, 100:45-47.

10. Berti J, Zimmerman R, Amarista J: Spatial and temporal distribution of Anopheline larvae in two malarious areas in Sucre state, Venezuela. Mem Inst Oswaldo Cruz 1993, 88(3):353-62.
11. Magris M, Rubio-Palis $Y$, Menares C, Villegas L: Vector bionomics and malaria transmission in the Upper Orinoco River, southern Venezuela. Mem Inst Oswaldo Cruz 2007, 102(3):303-11.

12. Moreno JE, Rubio-Palis Y, Páez E, Sánchez V: Abundance, biting behaviour and parous rate of Anopheline mosquito species in relation to malaria incidence in gold-mining areas of southern Venezuela. Med Vet Entomol 2007, 21(4):339-49.

13. Xavier MMSP, Rebêlo JMM: Species of Anopheles (Culicidae, Anophelinae) in a malaria-endemic area, Maranhão, Brazil. Rev Saúde Pública 1999, 33(6):535-41.

14. Gil LHS, Alves FP, Zieler H, Salcedo JMV, Durlacher RR, Cunha RPA, Tada MS, Camargo LMA, Camargo EC, Pereira-da-Silva LH: Seasonal malaria transmission and variation of Anopheline density in two distinct endemic areas in brazilian Amazon. J Med Entomol 2003, 40(5):636-41.

15. Klein TA, Lima JBP, Tada MS: Comparative susceptibility of Anopheline mosquitoes to Plasmodium falciparum in Rondonia, Brasil. Am I Trop Med Hyg 1991, 44:598-603.

16. Charlwood JD, Alecrim WA: Capture-recapture studies with the South American malaria vector Anopheles darlingi, root. Ann Trop Med Parasitol 1989, 83(6):569-76.

17. Manguin S, Roberts DR, Andre RG, Rejmankova E, Hakre S: Characterization of Anopheles darlingi (Diptera: Culicidae) larval habitats in Belize, Central America. J Med Entomol 1996, 33(2):205-11.

18. Rejmankova E, Rubio-Palis Y, Villegas L: Larval habitats of Anopheline mosquitoes in the Upper Orinoco, Venezuela. J Vector Ecol 1999, 24:130-137.

19. Vittor AY, Pan W, Gilman RH, Tielsch J, Glass G, Shields T, SánchezLozano W, Pinedo W, Salas-Cobos E, Flores S, Patz JA: Linking deforestation to malaria in the Amazon: characterization of the breeding habitat of the principal malaria vector, Anopheles darlingi. Am J Trop Med Hyg 2009, 81(1):5-12.

20. Souza-Santos R: Seasonal distribution of malaria vectors in Machadinho d'Oeste, Rondonia State, Amazon Region, Brazil. Cad Sau Pública 2002, 18(6):1813-18.

21. Guimarães AE, Gentile C, Alencar J, Lopes CM, Mello RP: Ecology of Anopheline (Diptera, Culicidae), malaria vectors around the Serra Mesa Reservoir, state of Goiás, Brazil. Caderno Sau Pub 2004, 20(1):291-302.

22. Gil LHS, Tada MS, Katsuragawa TH, Ribolla PEM, Pereira-da-Silva LH: Urban and suburban malaria in Rondonia (Brazilian Western Amazon) II. Perennial transmission with high anopheline densities are associated with human environmental changes. Mem Inst Oswaldo Cruz 2007, 102(3):271-76.

23. Tadei WP, Thatcher BD, Santos JMM, Scarpassa VM, Rodrigues IB, Rafael MS: Ecologic observations on anopheline vectors of malaria in the brazilian Amazon. Am J Trop Med Hyg 1998, 59(2):325-35.

24. Tadei WP, Santos JMM, Costa WLS, Scarpassa VM: Biologia de Anophelinos amazônicos XII. Ocorrência de espécies de Anopheles, dinâmica da transmissão e controle da malária na zona urbana de Ariquemes (Rondônia). Rev Inst Med Trop São Paulo 1988, 30(3):221-51.

25. Santos RL, Padilha A, Costa MD, Costa EM, Dantas-Filho HC, Povoa MM: Malaria vectors in two indigenous reserves of the Brazilian Amazon. Rev Saúde Pública 2009, 43(5):859-68.

26. Akhavan D, Musgrove P, Abrantes A, d'Gusmao R: Cost-effective malaria control in Brazil. Cost-effectiveness of a malaria control program in the Amazon Basin of Brazil 1988- 1996. Soc Sci Med 1999, 49:1385-1399.

27. Deane LM: Osbervações sobre a malária na Amazônia Brasileira. Rev Serv Saúde Publ 1947, 1:3-60.

28. Deane $L M: A$ cronologia da descoberta dos transmissores da malária na Amazônia Brasileira. Mem Inst Oswaldo Cruz 1989, 84(supp 4):149-56.

29. Moore SJ, Hill N, Ruiz C, Cameron MM: Field evaluation of traditionally used plant-based insect repellents and fumigants against the malaria vector Anopheles darlingi in Riberalta, Bolivian Amazon. J Med Entomol 2007, 44(4):624-30

30. Hiwat H, Issaly J, Gaborit P, Somai A, Samjhawan A, Sardjoe P, Soekhoe T, Girod R: Behavioral heterogeneity of Anopheles darlingi (Diptera: Culicidae) and malaria transmission dynamics along the Maroni River, Suriname, French Guiana. Trans Royal Soc Trop Med Hyg 2010, 104:207-13.

31. Lounibos LP, Conn JE: Malaria vector heterogeneity in South America. Am Entomol 2000, 46:238-49.

32. Conn JE, Vineis JH, Bollback JP, Onyabe DY, Wilkerson RC, Póvoa MM: Population structure of the malaria vector Anopheles darlingi in a 
malaria-endemic region of eastern Amazonian Brazil. Am J Trop Med Hyg 2006, 74(5):798-806.

33. Molina-Cruz A, Mérida AMP, Mills K, Rodríguez F, Schoua C, Yurrita MM, Molina E, Palmieri M, Black WC: Gene Flow among Anopheles albimanus populations in Central America, South America, and the Caribbean assessed by microsatellites and mitochondrial DNA. Am J Trop Med Hyg 2004, 71(3):350-59.

34. Scarpassa VM, Cardoza TB, Cardoso-Junior RP: Population genetics and phylogeography of Aedes aegypti (Diptera: Culicidae) from Brazil. Am J Trop Med Hyg 2008, 78(6):895-903.

35. Barón S, Martín-Sánchez J, Gállego M, Morales-Yuste M, Boussa S, MorillasMárquez F: Intraspecific variability (rDNA ITS and mtDNA Cyt $b$ ) of Phlebotomus sergenti in Spain and Morocco. Acta Tropica 2008, 107:259-267.

36. Moritz C, Downling TE, Brown WM: Evolution of animal mitochondrial DNA: relevance for population biology and systematics. Am Rev Ecol Syst 1987, 18:269-92.

37. Brown WM: The Mitochondrial Genome of Animals. In Molecular Evolutionary Genetics. Edited by: Macintyre RJ. New York: Plenum Press; 1985:95-130.

38. Harrison RG: Animal mitochondrial DNA as a genetic marker in population and evolutionary biology. Trends Ecol Evol 1989, 4:6-11.

39. Bracco JE, Capurro ML, Sallum MAM: Genetic variability of Aedes aegypti in the Americas using a mitochondrial gene: evidence of multiple introductions. Mem Inst Oswaldo Cruz 2007, 102(5):573-580.

40. Paduan KS, Ribolla PEM: Mitochondrial DNA polymorphism and heteroplasmy in populations of Aedes aegypti in Brazil. J Med Entomol 2008, 45(1):59-67.

41. Urdaneta-Marquez L, Bosio C, Herrera F, Rubio-Palis Y, Salasek M, Black WC Genetic relationships among Aedes aegypti collections in Venezuela as determined by mitochondrial DNA variation and nuclear single nucleotide polymorphisms. Am J Trop Med Hyg 2008, 78(3):479-91.

42. Angêlla AF, Gil LHS, Pereira-da-Silva LH, Ribolla PEM: Population structure of the malaria vector Anopheles darlingi in Rondônia, Brazilian Amazon, based on mitochondrial DNA. Mem Inst Oswaldo Cruz 2007, 102(8):953-58.

43. Conn JE, Mitchell SE, Cockburn AF: Mitochondrial DNA variation within and between two species of neotropical anopheline mosquitoes (Diptera: Culicidae). J Heredity 1997, 88:98-107.

44. Conn JE, Mitchell SE, Cockburn AF: Mitochondrial DNA analysis of the neotropical malaria vector Anopheles nuneztovari. Genome 1998, 41:313-27.

45. Costa RA, Leal O, Leal EAS: Evolução da infecção malárica no Município de Acrelândia, Estado do Acre (1999-2002). Rev Soc Bras Med Trop 2004, 37(Supp I):269.

46. Marrelli MT, Branquinho MS, Hoffmann EH, Taipe-Lagos CB, Natal D, Kloetzel JK: Correlation between positive serology for Plasmodium vivaxlike/Plasmodium simiovale malaria parasites in the human and anopheline populations in the State of Acre, Brazil. Trans R Soc Trop Med Hyg 1998, 92(2):149-51.

47. Scarpassa VM, Conn JE: Population genetic structure of the major malaria vector Anopheles darlingi (Diptera: Culicidae) from the Brazilian Amazon, using microsatellite markers. Mem Inst Oswaldo Cruz 2007, 102(3):319-327.

48. Sallum MAM, Marrelli MT, Nagaki SS, Laporta GZ, Santos CLS: Insight into Anopheles (Nyssorhynchus) (Diptera: Culicidae) species from Brazil. J Med Entomol 2008, 45(6):970-981.

49. Rosa-Freitas MG, Broomfiels $G$, Priestman A, Milligan PJM, Momen $H_{\text {, }}$ Molyneux DH: Cuticular Hydrocarbons, Isoenzymes and Behavior of Three Population of Anopheles darlingi from Brazil. J Am Mos Control Association 1992, 8(4):357-366.

50. Consoli RAGB, Lourenço-de-Oliveira R: Principais mosquitos de importância sanitária no Brasil. Rio de Janeiro: Editora Fiocruz; 1994.

51. Gorrochotegui-Escalante N, Munoz ML, Fernandez-Salas I, Beaty BJ, Black WC: Genetic isolation by distance among Aedes aegypti populations along the northeastern coast of Mexico. Am J Trop Med Hyg 2000, 62:200-09

52. Sambrook J, Fritsh EF, Maniats T: Molecular Cloning: a laboratory manual New York: Cold Spring Harbor Laboratory Press; 1989.

53. Thompson JD, Higgins DG, Gibson TJ: CLUSTAL W: improving the sensitivity of progressive multiple sequence alignment through sequence weighting, position specific gap penalties and weight matrix choice. Nucleic Acids Res 1994, 22:4673-4680.
54. Kumar S, Tamura K, Jakobsen IB, Nei M: MEGA2: Molecular evolutionary genetics analysis software. Bioinformatics 2001, 17:1244-1245.

55. Saitou N, Nei M: The neighbor-joining method: a new method for reconstructing phylogenetic trees. Mol Biol Evol 1987, 4:406-425.

56. Kimura M: A simple method for estimating evolutionary rates of base substitutions through comparative studies of nucleotide sequences. J Mol Evol 1980, 16:111-20.

57. Rozas J, Rozas R: DnaSP version 3: an integrated program for molecular population genetics and molecular evolution analysis. Bioinformatics 1999, 15:174-75.

58. Excoffier L, Laval G, Schneider S: Arlequin ver. 3.0: An integrated software package for population genetics data analysis. Evol Bioinf Online 2005, 1:47-50.

59. Lopes J, Lozovei AL: Ecologia de mosquitos (Diptera: Culicidae) em criadouros naturais e artificiais de área rural do Norte do Estado do Paraná, Brasil. I-Coletas ao longo do leito de ribeirão. Rev Saúde Pública 1995, 29(3):183-195.

60. Silva MAN, Lozovei AL: Criadouros de imaturos de mosquitos (Díptera, Culicidae) introduzidos em mata preservada na área urbana de Curitiba, Paraná, Brasil. Rev Brás Zool 1996, 13(4):1023-1042.

61. Vittor AY, Gilman RH, Tielsch J, Glass G, Shields T, Lozano WS, PinedoCancino V, Patz JA: The Effect of Deforestation on the Human-biting Rate of Anopheles darlingi, the primary Vector of Falciparum Malaria in the Peruvian Amazon. Am J Trop Med Hyg 2006, 74(1):3-11.

62. Lima D, Pozzobon J: Amazônia socioambiental: sustetabilidade ecológica e diversidade social. Estudos Avançados 2005, 19(54):45-76.

63. Tadei WP, Santos JMM, Scarpassa VM, Rodrigues IB: Incidência, Distribuição e Aspectos Ecológicos de espécies de Anopheles (Díptera: Culicidae) em regiōes naturais e sob impacto ambiental da Amazônia Brasileira. Bases Científicas para Estratégias de Preservação e Desenvolvimento da Amazônia 1993, 2:167-96.

64. Castro MC, Monte-Mó RL, Sawyer DO, Singer BH: Malaria risk on the Amazon frontier. PNAS 2005, 103:2452-57.

65. Silva-Nunes M, Codeço CT, Malafronte RS, Silva NS, Juncansen C, Muniz PT, Ferreira MU: Malaria on the Amazonian Frontier: transmission dynamics, risk factors, spatial distribution, and prospects for control. Am J Trop Med Hyg 2008, 79(4):624-35.

66. Silva NS, Silva-Nunes M, Malafronte RS, Menezes MJ, D'Arcadia RR Komatsu NT, Scopel KKG, Braga EM, Cavasini CE, Cordeiro JA, Ferreira MU: Epidemiology and control of frontier malaria in Brazil: lessons from community-based studies in rural Amazonia. Trans $R$ Soc Trop Med Hyg 2010, 104(5):343-50.

67. Silva-Nunes M, Malafronte RS, Luz BA, Souza EA, Martins LC, Rodrigues SG, Chiang JO, Vasconcelos PFC, Muniz PT, Ferreira MU: The Acre Project: the epidemiology of malaria and arthropod-borne vírus infections in a rural Amazonian population. Cad Saúde Pública 2006, 22(6):1325-1334.

68. Yasuoka J, Levins R: Impact of deforestation and agricultural development on anopheline ecology and malaria epidemiology. Am J Trop Med Hyg 2007, 76(3):450-460.

69. Nagm L, Luitgards-Moura JF, Neucamp CS, Monteiro-de-Barros FS, Honório NA, Tsouris P, Rosa-Freitas MG: Affinity and diversity indices for anopheline immature forms. Rev Inst Med Trop S Paulo 2007, 49(5):309-316.

70. Macauley C: Aggressive active case detection: a malaria control strategy based on the Brazilian model. Social Science \& Medicine 2005, 60:563-573.

71. Tadei WP, Thatcher BD: Malaria vectors in the Brazilian Amazon Anopheles of the subgenus Nyssorhynchus (1). Rev Inst Med Trop S Paulo 2000, 42(2):87-94.

72. Forattini OP: Exophilic behaviour of Anopheles darlingi root in a southern region of Brazil. Rev Saude Publ 1987, 21(4):291-304.

73. Orjuela-Sánchez P, Silva NS, Silva-Nunes M, Ferreira MU: Recurrent parasitemias and population dynamics of Plasmodium vivax polymorphisms in rural Amazonia. Am J Trop Med Hyg 2009, 81(6):961-968.

doi:10.1186/1475-2875-10-174

Cite this article as: Moutinho et al:: Population dynamics, structure and behavior of Anopheles darlingi in a rural settlement in the Amazon rainforest of Acre, Brazil. Malaria Journal 2011 10:174. 